Studia Anglica Posnaniensia 51/2, 2016

doi: 10.1515/stap-2016-0007

\title{
BIDE NU AET GODE PAET IC GRECISC CUNNE: ATTITUDES TO GREEK AND THE GREEKS IN THE ANGLO-SAXON PERIOD*
}

\author{
OlgA TIMOFEEVA**
}

University of Zurich

\begin{abstract}
The Greeks were one of those outgroups to whom the Anglo-Saxons had reasons to look up to, because of the antiquity of their culture and the sanctity of their language, along those of the Hebrews and the Romans. Yet as a language Greek was practically unknown for most of the Anglo-Saxon period and contact with its native speakers and country extremely limited. Nevertheless, references to the Greeks and their language are not uncommon in the Anglo-Saxon sources (both Latin and vernacular), as a little less than 200 occurrences in the Dictionary of Old English (s.v. grecisc) testify.

This paper uses these data, supplementing them with searches in the Dictionary of Old English Web Corpus, Brepolis Library of Latin Texts - Series A, monumenta.ch and Medieval Latin from Anglo-Saxon Sources, and analyses lexical and syntactic strategies of the Greek outgroup construction in Anglo-Saxon texts. It looks at lexemes denoting 'Greek' and their derivatives in Anglo-Latin and Old English, examines their collocates and gleans information on attitudes towards Greek and the Greeks, and on membership claims indexed by Latin-Greek or English - Greek code-switching, by at the same time trying to establish parallels and influences between the two high registers of the Anglo-Saxon period.
\end{abstract}

Keywords: Old English, Anglo-Latin, outgroup construction, flagged code-switching, etymology, Greek

I wish to thank Matti Kilpiö and my anonymous reviewer for their valuable comments and suggestions, as well as the audiences of the SELIM conference at Granada in 2015 and HiSoN at Helsinki in 2016 for their feedback on the earlier versions of this paper. The usual disclaimers apply.

** olga.timofeeva@es.uzh.ch, University of Zurich, English Department, Plattenstrasse 47, CH-8032 Zurich, Switzerland. 


\section{Introduction}

The Greek language and culture inspired admiration and awe among Roman poets and writers who looked up to Greek poetry, sculpture, philosophy, rhetoric, and science, always attempting to imitate them and always finding themselves inferior to Greek arts and knowledge. Ample evidence for this can be found in many authors, e.g. Horace, famously, says, Graecia capta ferum victorem cepit et artes / intulit agresti Latio (Ep.2,1,156-157) 'Conquered Greece took captive her savage conqueror and brought her arts into rustic Latium,' which is echoed by Cicero's Doctrina Graecia nos et omni litterarum genere superabat (Cic.Tusc.1,3) 'Greece surpassed us in learning and in every genre of literature'. ${ }^{1}$ The Late Antiquity inherits this attitude (Adams 2003), and, with the rise of Christianity, the cult of Greek verbal arts continues, even though the knowledge of Greek as a language in Western Europe in general, let alone such remote places as Britain, becomes rare (Bodden 1988; Dionisotti 1988; Lapidge 1988).

The ideological foundation for the importance of Greek in the Middle Ages lies in its inclusion within the trinity of sacred languages alongside Hebrew and Latin (Sawyer 1999: 23-43). Resting on the authority of the Gospels (John 19:19-20; Luke 23:38; cf. Matt 27:37; Mark 15:26), early medieval writers from Augustine and Prudentius to Bede and Alcuin hailed Hebrew, Greek, and Latin, in which Jesus of Nazareth, the King of the Jews was written by Pontius Pilate above the cross. For example, in Isidore's Etymologies (1) we read:

(1) Tres sunt autem linguae sacrae: Hebraea, Graeca, Latina, quae toto orbe maxime excellunt. His enim tribus linguis super crucem Domini a Pilato fuit causa eius scripta. (Etym ix.1.3)

'There are three sacred languages, Hebrew, Greek, and Latin, which are supreme in the whole earth. For in these three languages Pilate wrote above the cross of the Lord the charge against him.'

Explaining the importance of the three languages in Roman Judaea in his commentary on John (2), Augustine wrote:

(2) hae quippe tres linguae ibi prae ceteris eminebant: hebraea, propter iudaeos in dei lege gloriantes; graeca, propter gentium sapientes; latina, propter romanos multis ac pene omnibus iam tunc gentibus imperantes. (In Iohannis euangelium tractatus 117.4.6)

\footnotetext{
Cf. also other well-known passages: Horace Ars 323-326, Cicero De orat. 2.18, Virgil Aen
} 6.847-853, etc., etc. 
'For these three languages were conspicuous in that place beyond all others: the Hebrew on account of the Jews, who gloried in the law of God; the Greek, because of the wise men among the Gentiles; and the Latin, on account of the Romans, who at that very time were exercising sovereign power over many and almost all countries.'

The same explanation (taken over mostly verbatim) was used by Bede in his In Lucae euangelium expositio (vi.23.1652) and later on by Alcuin in Commentaria in sancti Iohannis Euangelium (981.24).

Old English texts seem to reflect this idea of the uniqueness of the sacred three, in that, first of all, Hebrew, Greek, and Latin collocate frequently with one another or even appear in a sequence. King Alfred advocates the benefits of the translation from Hebrew to Greek to Latin, which brings the law of God to the western world, in his preface to the translation of the Pastoral Care (3).

(3) Đa gemunde ic hu sio æ wæs ærest on Ebreisc geðiode funden, \& eft, ða hie Creacas geliornodon, ða wendon hie hie on hiora agen geðiode ealle, \& eac ealle oðre bec. \& eft Lædenware swæ same, siððan hie hie geliornodon, hie hie wendon <ealla $>$ ðurh wise wealhstodas on hiora agen geðiode. Ond eac ealla oðræ Cristnæ ðioda sumne dæl hiora on hiora agen geðiode wendon. (CPLetWærf 43-47)

'Then I remembered how the law was first composed in the Hebrew language, and afterwards, when the Greeks had learned it, they translated it all into their own language, and also all other books. And afterwards the Romans in the same way, when they had learned them, translated them all through wise interpreters into their own language. And also all other Christian peoples translated some part of them into their own language.'

In his homily on the Assumption of the Virgin, Ælfric treats Jerome's command of Greek and, especially, of Hebrew as something extraordinary (4).

(4) Đes hieronimus wæs halig sacerd \& getogen on hebreiscum gereorde. \& on greciscum. $\&$ on ledenum fulfremedlice $\&$ he awende ure bibliothecan of hebreiscum bocum to ledenspræce. He is se fyrmesta wealgstod betwux hebreiscum. \& grecum. \& ledenwarum. (ÆCHom I,30 429.9-12) 'This Jerome was a holy priest, and instructed in the Hebrew tongue, and in Greek and Latin perfectly; and he turned our library of Hebrew books into the Latin speech. He is the first interpreter betwixt the Hebrews, and Greeks, and Latins.' (trans. by Thorpe 1844: i.437) 
It is important that the sequence of the sacred languages is also hierarchical, and that the second position of Greek is meaningful precisely because, as the language of the Septuagint and, especially, the New Testament, it is an intermediary between Hebrew and Latin.

Standing both for the ancient knowledge and biblical sanctity, how real is Greek as a language? What is the purpose of Greek etymologies and codeswitches in Anglo-Saxon texts? How much is Greek related to Greece, Byzantium, and the people who lived and continue to live in the shrinking Eastern Empire in the Middle Ages?

Scholars have tried to answer such questions by using two types of evidence: the quality of Greek in the surviving Anglo-Saxon texts (Bodden 1988; Lapidge 1988; Feulner 2000) and the availability of textbooks (or books that might pass as such) for the study of Greek (Dionisotti 1988). These two reveal, on the one hand, a huge and diverse Greek vocabulary used in Anglo-Saxon sources and a great love for Greek words, phrases, quotations, prayers, etc. Bodden estimates that "[m]ore than half of the extant manuscripts from Anglo-Saxon England, both vernacular and Latin, contain Greek" and that "the cumulative Greek vocabulary" of Anglo-Saxon writers "could have run to about 5,000 words" (1988: 217, 224); the count for Greek loanwords in Old English before 1100 is, however, estimated at about 250 (Feulner 2000: 55-391; see also Miller 2012: 53-90; Durkin 2014: 158-161). On the other hand, these numbers come with "a noteworthy absence of Greek grammatical materials" (Bodden 1988: 226) and very limited familiarity with Greek grammar and syntax (232). With Greek vocabulary being transmitted chiefly in glossaries and being available and accessible only to the most educated among the cultural elite, the application of Greek became marked, generating a kind of a scientific jargon, hermeneutic and exclusive in its function (Dionisotti 1988: 31; Lapidge 1975; cf. also Stephenson 2009). It is quite telling that even in Italy a commoner's knowledge of Greek could only be accounted for by a miracle. ${ }^{2}$ In his Dialogues (iv.26), Pope Gregory tells a story of a simple youth who lived in a lawyer's house and, contracting a pest of some kind, fell into a trance in which he travelled to the other world and learnt who among the lawyer's household were going to die of the same disease. Coming to himself for a short while, he called for his master to tell him the names of those doomed to share his fate, and, as a proof that his words were true and the knowledge divinely inspired, he said he could now

2 The title of this article is taken from another miracle story, Ælfric’s version of the Life of St Basil of Caesarea from his Lives of Saints. One of its episodes describes Basil's meeting with Ephrem the Syrian (ÆLS (Basil) 514). At first they talk through an interpreter, but later on Ephrem wants Basil to pray for him and ask God to grant him the gift of speaking Greek. They kneel together and the prayer is granted. For an interpretation of the gift-oftongues miracles (including St Basil and St Ephrem's story), see Cooper-Rompato (2010). 
speak any language. He was then tested and addressed first in elevated Greek and next in barbarous Bulgarian, in both of which he was able to converse freely and was tried no more. I quote an excerpt from this account here in the Old English translation (version C) of the Dialogues (5).

(5) Ac wite pu, pæt ic pe andette \& sæcge to soðe, pæt ic wæs on heofonum \& ðær onfeng, pæt ic mæg sprecan on ælce gepeode. Cwypst pu, pæt pe nære cuð, pæt ic ne cuðe Grecisc gepeode? \& ponne hwæpre sprec nu on Grecisc, pæt pu ongyte, hwæper hit soð sy pe ne sy, pæt ic sæcge, pæt ic fenge pær ælcum gepeode. (GDPref and 4 (C) (27.300.13-15))

'And may you be assured that what I confess and say to you is true, that I have been in heaven and have there received the gift to speak in all tongues. Will you not agree that you were aware that I hadn't known the Greek tongue? And yet now I (will) speak Greek, that you may see whether it be true or not when I say that I have received the gift to understand all tongues.'

Coming back to Anglo-Saxon England, any extensive knowledge of Greek could be attributed either to a piece of historical luck, like the arrival of Theodore and Hadrian and the work of their seventh-century school of Canterbury (Lapidge 1988), or to an intellectual miracle, like Bede's deductive learning of Greek grammar by close study of bilingual biblical texts and patristic commentaries (Dionisotti 1988: 3). But these are clearly exceptional examples. What was common practice then? How was Greek used? Why would the Anglo-Saxons engage in Greek code-switching? Is it possible to glean any opinions or attitudes behind the mystical plethora of linguistic sanctity?

The following corpus study is meant to address these questions. Below I briefly describe my research corpus, the divisions into datasets within it and my data selection procedure (section 2), and then go on to introduce my results and analysis (section 3). My aim is to highlight lexical and syntactic strategies of the Greek outgroup construction in Anglo-Saxon texts, moving from the AngloLatin dataset to the Old English one, trying to establish parallels and influences between the two high registers of the Anglo-Saxon period. Because the majority of my examples do not only refer to the Greek language but also introduce Greek terminology on a variety of subjects, I also discuss flagged codeswitching and its functions in my corpus. Other pragmatic aspects of Greek within Latin and Old English texts are addressed in discussion (section 4). The results of the study are summarised in conclusions (section 5). 


\section{Data}

I have collected the lexemes denoting 'Greek' and their derivatives in AngloLatin and Old English from four corpora: the Dictionary of Old English Web Corpus (DOEC, for Old English), Brepolis Library of Latin Texts - Series A (LLT-A), monumenta.ch and Medieval Latin from Anglo-Saxon Sources (for Anglo-Latin). The two major datasets - Anglo-Latin and Old English - are kept and evaluated separately. Four datasets were excluded from the search in the DOEC: categories C (glosses), D (glossaries), E (Runic inscriptions), and F (non-Runic inscriptions). The general statistics of the two datasets are presented in Tables 1 and 2, which provide the word counts of individual authors/text categories, the relative portions of individual authors/text categories within the respective dataset, the absolute numbers of the tokens 'Greek', their relative portion within the dataset, and, finally, the normalised frequencies of tokens 'Greek' per 10,000 words.

The Anglo-Latin dataset is represented by three authors (chronologically): Aldhelm of Malmesbury (d. 709/10, b. and fl. in Wessex), the Venerable Bede (673/4-735, b. and fl. in Northumbria), and Alcuin (c.740-804, b. in Northumbria, fl. in Francia). Other authors and anonymous texts were also considered but did not return any search results. Being the earliest extensive samples of literary prose and poetry produced by the Anglo-Saxons, their works, on the one hand, provide a link between continental and insular written practices in Latin, and, on the other, supplement the written records of the OE1 period (from the first surviving texts in OE until 850, in the Helsinki-Corpus dating tradition) (Timofeeva 2013: 204-207, 217). I am going to argue that in the 'Greek' data one observes clear continuities between the two datasets in terms of how the respective Latin and Old English lexemes collocate and what contexts they prefer. Thus OE, with its textual evidence growing only after 850 , and especially following the intellectual revival of the 890 s, adopts conceptual associations that have already existed in Anglo-Latin and reformulates them in the vernacular.

Table 1. Anglo-Latin subcorpus: Data summary

\begin{tabular}{lrrrrr}
\hline & word counts & relative portion & 'Greek' N & Greek' \% & $\begin{array}{c}\text { normalised } \\
\text { frequencies / } \\
10,000 \text { words }\end{array}$ \\
\hline Aldhelm & 27,153 & $2.40 \%$ & 7 & $1.20 \%$ & 2.58 \\
Bede & 932,452 & $82.59 \%$ & 529 & $90.43 \%$ & 5.67 \\
Alcuin & 169,422 & $15.01 \%$ & 49 & $8.38 \%$ & 2.89 \\
\hline Totals & $1,129,027$ & $100.00 \%$ & 585 & $100.01 \%$ & 5.18 \\
\hline
\end{tabular}


As shown in Table 1, Bede is by far the greatest contributor both to the AngloLatin subcorpus and to the number of tokens in which the stem graec* (in two spelling variants $<$ graec*/græc $^{*}>$ ) occurs. Two texts in particular produce an imbalance in normalised frequencies: the 139 occurrences of graec* in his second commentary on the Acts of the Apostles (Retractatio in Actus apostolorum, 14,915 words) and 71 more in De orthographia (8,440 words). If these tokens and word counts are removed from the subcorpus, we get 319 tokens for Bede's overall portion of 909,097 words, or 3.51 per 10,000 words.

The OE subcorpus (Table 2) is subdivided slightly differently. First of all, as the total word count I use the figures provided by the DOEC (Word count tool $<$ http://tapor.library.utoronto.ca/doecorpus/wordcount.html $>$ ) for categories A (poetry) and B (prose). Within these I have separated authors and communities of practice that contribute a particularly high number of tokens ${ }^{3}$ (with descending absolute numbers): Byrhtferth of Ramsey (fl. c.986-c.1016) and his manual on computus Enchiridion, medical texts and compilations from a variety of periods and geographical locations, all of Ælfric of Eynsham's (c.950c.1010) works, and all the Alfredian translations from around 890. All the remaining A and B texts are treated as 'Other' category, irrespective of whether or not the stem grec* (in multiple spelling variants $<\mathrm{grec}^{*} / \mathrm{grek}^{*} / \mathrm{crec}^{*} / \mathrm{creac}^{*} / \mathrm{etc} .>$, see DOE, s.v. grecisc, for a complete list) is attested in the individual texts.

Table 2. Old English subcorpus: Data summary

\begin{tabular}{lrrrrc}
\hline & word counts & $\begin{array}{c}\text { relative } \\
\text { portion }\end{array}$ & 'Greek' N & 'Greek' \% & $\begin{array}{c}\text { normalised } \\
\text { frequencies / } \\
10,000 \text { words }\end{array}$ \\
\hline Byrhtferth of Ramsey & 20,316 & $0.88 \%$ & 30 & $9.46 \%$ & 14.77 \\
medical compilations & 82,132 & $3.56 \%$ & 47 & $14.83 \%$ & 5.72 \\
Elfric of Eynsham & 482,468 & $20.92 \%$ & 70 & $22.08 \%$ & 1.45 \\
Alfredian translations & 386,517 & $16.76 \%$ & 109 & $34.38 \%$ & 2.82 \\
Other & $1,334,828$ & $57.88 \%$ & 61 & $19.24 \%$ & 0.46 \\
\hline Totals (A+B) & $2,306,261$ & $100.00 \%$ & 317 & $99.99 \%$ & 1.37 \\
\hline
\end{tabular}

3 Cf. Feulner, who also treats data from Ælfric, Byrhtferth, OE Herbarium, Alexander's Letter to Aristotle with the Wonders of the East, and the poem Aldhelm separately (2000: 442-480). 
A comparison of Tables 1 and 2 reveals that the distribution of the lexemes in the two datasets is uneven. Although the Anglo-Latin subcorpus is two times smaller than the Old English one, the number of tokens is much higher in the former (585) than in the latter $\left(317^{4}\right)$. In normalised frequencies per 10,000 words this gives us 5.2 in Anglo-Latin as opposed to 1.4 in Old English. A more balanced picture emerges if a few adjustments are made for both datasets: 1) when the Retractatio in Actus apostolorum and De orthographia by Bede are excluded from count, we get a total of 375 tokens and a total of 3.39/10,000 words in Anglo-Latin; 2) when the 'Other' category with underuse of 'Greek' (61 tokens/1,334,828 words) and the Old English Orosius, that deals explicitly with Greek history, with overuse of 'Greek' (76 tokens/51,110 words) are excluded from count, we get a total of 180 tokens and a total of $1.96 / 10,000$ words in OE. Thus learned texts in Anglo-Latin refer to 'Greek' almost two times as frequently as $\mathrm{OE}$ learned texts, which is still a considerable difference. Is there any reason why Greek is more important for authors writing in Latin rather than English? As is very often the case with historical studies of lexis in this period, statistics tell us more about the distribution of genres in the two datasets than about the lexemes themselves (or at least as much about both). The abundance of handbooks and scientific treatises on grammar and rhetoric and of biblical commentaries in Anglo-Latin explains the higher proportion of Greek material in this subcorpus. While the general paucity of such texts as the Old English Orosius, dealing directly with episodes of Greek history, or as Byrhtferth's Enchiridion in the vernacular accounts for different distributions in the Old English subcorpus. Before drawing any further conclusions, a more detailed analysis of collocations with 'Greek' is in place.

\section{Analysis}

\subsection{Etymologies}

The same genre dependency is reflected at the level of relative frequencies. Of all occurrences in the Anglo-Latin subcorpus 73 per cent refer explicitly to Greek etymology of or provide a contextual gloss for a Greek word or phrase. Table 3 provides a list of possible collocates.

4 This is over a hundred more than the DOE entry states (s.v. grecisc). 
Table 3. 'Greek' in etymologies, translations, in collocations with 'language', 'word', etc. (Anglo-Latin subcorpus)

\begin{tabular}{lrr}
\hline ex uno graeco 'from a Greek (word/phrase)' & 21 & $4.91 \%$ \\
graece 'in Greek' & 181 & $42.29 \%$ \\
Greek (text/original) reads/has & 32 & $7.48 \%$ \\
Greek language/speech/diction & 40 & $9.35 \%$ \\
Greek word/name/noun & 28 & $6.54 \%$ \\
in graeco 'in Greek' & 126 & $29.44 \%$ \\
\hline Total & 428 & $100.01 \%$ \\
\hline
\end{tabular}

Most frequently (close to 72 per cent) a direct link between a Greek lemma and Latin interpretamentum is established by using the adverb graece (181 tokens) or the prepositional phrase in graeco (126 tokens), both meaning 'in Greek'. The Greek lemmata can be given in the original alphabet (6-7) - increasingly so in the late Anglo-Saxon period - or transliterated in Latin (see (9); cf. Bodden 1988: 218-219; my examples follow the orthography of the LLT-A corpus):

(6) Graece enim aqua v̋ $\delta \omega \rho$ dicitur (Alc_IohEv 767.33) 'In Greek aqua is called hydōr'

(7) dispersi sunt, in Graeco dicitur $\delta 1 \varepsilon \sigma \pi \alpha ́ \rho \eta \sigma \alpha v$, id est disseminati sunt, (Bede_InCantCant6 i.1.310)

'they were dispersed, in Greek it is said diesparēsan, that is, they were disseminated'

It is important that the examples like (6) and (7) are instances of flagged codeswitching (for data on unflagged code-switching into Greek, see Feulner 2000). Not only do they provide an etymological commentary on the biblical text (the Gospel of John in (6) and the Song of Songs in (7)), but also attest to their authors' proficiency in Greek. Considering that in many cases (see also examples below) these switches are spelt in Greek characters, we would assume that the audiences of such texts, i.e. the immediate communities of practice that Bede and Alcuin were working within - the monks of Wearmouth-Jarrow and the scholars at Charlemagne's court, must have shared the linguistic repertoire of their authors. This does not mean that Bede and Alcuin and their audience were trilingual, rather this confirms what previous research has highlighted, namely that limited literacy in Greek was not uncommon (cf. Bodden 1988; Dionisotti 1988). Thus this type of code-switching affirms membership of a social category (the clergy, or rather the educated elite thereof) and can be viewed as an act of identity. I return to this problem in the discussion (section 4). 
The PP in graeco can also be used without an explicit citation from Greek (8).

Sequuntur in hoc loco duo uersus in Graeco (Bede_ExpActAp 18.18)

'This place is followed by two verses in Greek'

In this case Bede notes that two verses are missing in his Latin text of the Acts of the Apostles. This confirms the claim that he had manuscripts in Greek at his disposal and compared them against the Latin text of Jerome (for more details on the 'Northumbrian Bible', see Hunter Blair 1990: Ch. 21).

The examples above would suggest that the adverbials graece and in graeco are synonymous. I would argue that the abundance of in graeco in my data may also have a language-acquisition explanation. Considering that in the complete LLT-A (that includes both classical and medieval authors) the adverb graece is used almost 2.5 times more frequently than the PP in graeco $(2,265$ and 951 tokens), while in Anglo-Latin the relation is 181 to 126, i.e. only about 1.5 times as many, it would seem probable that in graeco is partly triggered by the L1 transfer of the equivalent on grecisc PP from OE (cf. Table 4).

In the remaining data the connection between 'Greek' and the written educated milieu, in which it is used, is strongly emphasised by such collocates as nomen, verbum, vocabulum, sententia, lingua, sermo or by an elliptical reference a Greek word, phrase, text, original (9-11).

(9) Ecclesia et sinagoga Graeca nomina sunt (Bede_InProvSal i.5.66)

'Ecclesia and synagogue are Greek words'

(10) Topazium vero pretiosus lapis est; et quia Graeca lingua $\pi \tilde{\alpha} v$ omne dicitur, (Alc_C_Haeresin_Felicis xxiv)

"Topaz is a precious stone; and it is called pān "everything" in the Greek language'

(11) Omelia graecum est; latine sermo uel colloquium. (Bede_DeOrth 787)

'Homilia is Greek; in Latin (we say) sermo or colloquium'

In these examples, too, code-switching is flagged in a variety of ways, although the Greek words themselves can be transliterated as in (9) and (11). It is only exceptionally that we find a reference to Greek outside the immediate context of books and etymologies. For example, the students of Theodore and Hadrian are several times singled out for their command of Greek in Bede's Historia Ecclesiastica: 
(12) eorum discipulis, qui Latinam Graecamque linguam aeque ut propriam in qua nati sunt norunt. (Bede_HE iv.2.1)

'their students, who know Latin and Greek just as well as their own native language'

The same tendencies are relevant for the Old English subcorpus (Table 4). Direct references to Greek etymologies, meanings, words and phrases also constitute the greatest portion of the data; their relative value, however, is only 33 per cent of all occurrences, with the association of Greek with written culture being strong in both datasets.

Table 4. 'Greek' in etymologies, translations, in collocations with 'language', 'word', etc. (Old English subcorpus)

\begin{tabular}{lrr}
\hline on grecisc & 53 & $49.53 \%$ \\
Greek language/speech & 24 & $22.43 \%$ \\
Greek word/name & 21 & $19.63 \%$ \\
Greek (language) & 9 & $8.41 \%$ \\
\hline Total & 107 & $100.00 \%$ \\
\hline
\end{tabular}

The PP on grecisc accounts for half of the occurrences in this subset. Of these 23 are found in Byrhtferth's Enchiridion (13). Both in him and other authors on grecisc typically introduces an interpretamentum in English or in Latin and English (13-14). The same is true about such collocates as grecisc* + nama, word; gereord, sprcec, etc. (15).

(13) Seo wucu on Grecisc hatte ebdomada and on Lyden septimana. (ByrM 1 (Baker/Lapidge) (2.3.108))

'The week in Greek is called hebdomada and in Latin septimana'

(14) GRAMMA on grecisc is LITTERA on leden and on englisc stæf, and GRAMMATICA is stæfcræft. (ÆGram (289.9))

'gramma in Greek is littera in Latin and letter in English, and grammatika is the art of letters'

(15) Ælc mæssepreost sceal beon swa he gehaten is sacerd, pæt is grecisc word \& is on leden sacrum dans \& on ure geðeode halig syllend. (Conf 3.1.1 (Raith Y) (3.16))

'Every masspriest ought to behave so that he is called sacerd, that is a Greek word ${ }^{5}$; and in Latin sacrum dans and in our language holy giver'

5 Mistaken etymology, sacerd is in fact of Latin origin. 
The authors that feature prominently in this subset are Ælfric and Byrhtferth. Their contributions to the data are 45 and 25 tokens, respectively, i.e. two thirds of the subset. In Ælfric 27 tokens come from his Grammar. Thus the majority of etymological and other linguistics references occur in handbooks and scientific treatises. The majority of them, as examples (13) and (14) attest, are flagged code-switches as in the Anglo-Latin subcorpus. Is their function the same as that of Latin-to-Greek switches discussed earlier on? As before social membership and audience are to be considered. Both Ælfric and Byrhtferth belong to the same second generation of scholars associated with the Benedictine reform, they adhere to the same monastic rule, share similar education (Jones 2009: 95-108) and read the same canon of literature, their teachers belong to the same circle (the first Benedictine generation) (Lenker 2000). Because the Benedictine movement is associated with improved education standards, to the extent that the prime Latinists taking part in it become notorious for their complicated 'hermeneutic' style (Lapidge 1975), it would seem logical that the two younger representatives of the movement exhibit signs of their superior education even in their OE writings. Greek codeswitching can thus be interpreted as an act of identity that affirms group membership, membership of the Benedictine-movement associates. On the other hand, the two handbooks are written in Old English - most of Ælfric's Grammar and about a half of Byrhtferth's Enchiridion. This clearly does not presuppose the same level of education of the two authors vs. the audience of the two texts; in his preface Ælfric states that he intends his work for beginner students of Latin, for whom an elementary OE textbook would be a useful introduction. I suggest that code-switching into Greek in this situation serves to establish and enhance the authority of Ælfric and Byrhtferth as teachers, while glossing and explaining the switches in OE serves to include students into the group of the literati although at a novice level. Thus the membership is affirmed in so many subtle ways, but also intra-group boundaries within the member group are clearly marked, with etymology and grammar, to use the standard metaphor of the period, being a key to greater knowledge (cf. stcefcrceft is seo caeg, ðе ðcera boca andgit unlicð (ÆGram 2.13) 'Grammar is the key that unlocks the meaning of books'), an encouragement to persevere and to become full members.

\subsection{Other NPs}

Moving on to other nouns that collocate with the adjective 'Greek', we can see that in the Latin dataset the connection to the written world is still predominant (Table 5): we have Greek characters, manuscripts, writers, teachers, libraries, and only exceptionally earthly things like amphorae, houses, wine or women. 
Table 5. 'Greek' in collocations with other nouns (Anglo-Latin subcorpus)

\begin{tabular}{lcc} 
Greek characters & 9 & $17.31 \%$ \\
Greek authority & 6 & $11.54 \%$ \\
Greek codices & 4 & $7.69 \%$ \\
Greek custom & 4 & $7.69 \%$ \\
Greek etymology/source & 3 & $5.77 \%$ \\
Greek month & 3 & $5.77 \%$ \\
Greek ambiguous (phrase) & 2 & $3.85 \%$ \\
Greek computation & 2 & $3.85 \%$ \\
Greek history & 2 & $3.85 \%$ \\
Greek translator & 2 & $3.85 \%$ \\
Greek writer/poet & 2 & $3.85 \%$ \\
Greek accuracy & 1 & $1.92 \%$ \\
Greek amphora & 1 & $1.92 \%$ \\
Greek (grammatical) case & 1 & $1.92 \%$ \\
Greek evidence & 1 & $1.92 \%$ \\
Greek faith & 1 & $1.92 \%$ \\
Greek house & 1 & $1.92 \%$ \\
Greek library & 1 & $1.92 \%$ \\
Greek masters/teachers & 1 & $1.92 \%$ \\
Greek murmur & 1 & $1.92 \%$ \\
Greek numbers & 1 & $1.92 \%$ \\
Greek reign & 1 & $1.92 \%$ \\
Greek wine & 1 & $1.92 \%$ \\
Greek women & 52 & $1.92 \%$ \\
\hline Total & $99.98 \%$ \\
\hline
\end{tabular}

The authority of a Greek source can be emphasised quite literally, as in (16).

(16) Verum si Graecam inspexerimus auctoritatem ubi scriptum est: (Bede_RetInActAp 2.120)

'Truly, if we analyse the Greek authority (= text) where it was written.'

References to household items are rare, they are typically found in gloss-like commentaries (17): 
(17) Cadus graeca amphora est continens urnas tres (Bede_InLucEv v.16.75)

'Cadus, (or) Greek amphora, contains three urns.'

In the Old English dataset, however, which is relatively bigger, we come across political rather than cultural noun phrases with Greek cities, armies, kings, ships, nobles, and elders. Here, again, we are dealing with one of those imbalances created by the genre differences within the two subcorpora. For example, 5 out of 5 occurrences of 'Greek army' are found in the Alexander's Letter to Aristotle, while 13 out of 16 occurrences of 'Greek cities' in the Old English Orosius (see section 2 on Data), both texts dealing explicitly with Greek matters, with many other collocates being also unique to the latter source.

Table 6. 'Greek' in collocations with other nouns (Old English subcorpus)

\begin{tabular}{lrr}
\hline Greek city/capital & 16 & $29.63 \%$ \\
Greek army & 5 & $9.26 \%$ \\
Greek characters & 5 & $9.26 \%$ \\
Greek king & 4 & $7.41 \%$ \\
Greek kingdom & 4 & $7.41 \%$ \\
Greek custom & 2 & $3.70 \%$ \\
Greek descent & 2 & $3.70 \%$ \\
Greek empire & 2 & $3.70 \%$ \\
Greek lord & 2 & $3.70 \%$ \\
Greek powers/strength & 2 & $3.70 \%$ \\
Greek ships & 2 & $3.70 \%$ \\
Greek books & 1 & $1.85 \%$ \\
Greek elders & 1 & $1.85 \%$ \\
Greek faith & 1 & $1.85 \%$ \\
Greek monks & 1 & $1.85 \%$ \\
Greek nobles & 1 & $1.85 \%$ \\
Greek poison & 1 & $1.85 \%$ \\
Greek shrine & 1 & $1.85 \%$ \\
Greek stronghold & 1 & $1.85 \%$ \\
\hline Total & 54 & $99.97 \%$ \\
\hline
\end{tabular}


(18) illustrates a characteristic use in the Old English Orosius:

(18) Wyð eastan Constantinopolim Creca byrig is se sæ Proponditis. (Or 1 $(1.18 .4))$

'To the east of the Greek city of Constantinople is the Sea of Marmara.'

As (18) and Table 6 would suggest, common notions about Greek geography, administration, and political history were available to Anglo-Saxon audiences even in Old English (see also below, esp. 3.5). Classical and patristic sources, such as Pliny, Eusebius of Caesarea, Orosius, Isidore, etc., as the circulation of their manuscripts and citations in major Anglo-Saxon works attest (Lapidge 2006: 302, 311, 323, 325), would have provided a lot of historical and cultural information in Latin, and much of the scholarly facts and Greek etymologies too. The occasions to quote the latter, however, were much more numerous.

\subsection{Verb collocates}

The next illustration presents collocates of plural subject NPs ('Greeks') with verbs (Table 7).

Table 7. 'Greeks' in collocations with verbs (Anglo-Latin subcorpus)

\begin{tabular}{lrr}
\hline Greeks call/name/say & 36 & $44.44 \%$ \\
$\mathrm{X}$ is called Y among/by the Greeks & 22 & $27.16 \%$ \\
Greeks measure/compute & 9 & $11.11 \%$ \\
Greeks observe & 4 & $4.94 \%$ \\
Greeks excel in knowledge & 2 & $2.47 \%$ \\
Greeks read & 2 & $2.47 \%$ \\
Greeks assemble & 1 & $1.23 \%$ \\
Greeks hear/learn & 1 & $1.23 \%$ \\
Greeks disagree & 1 & $1.23 \%$ \\
Greeks mention & 1 & $1.23 \%$ \\
Greeks search for knowledge & 1 & $1.23 \%$ \\
Greeks seize smb & 1 & $1.23 \%$ \\
\hline Total & 81 & $99.98 \%$ \\
\hline
\end{tabular}


Most of the instances presented in Table 7 have graeci as subject, as in (19).

(19) quas ob id graeci pluuio nomine hyadas appellant (Bede_DeNatRer 11.11)

'for this reason the Greeks call pluvio by the word hyadas'

A semantically equivalent construction has a passive verb and a PP with graeci in the ablative (20) or accusative (21) (23 per cent of the data in this subset).

(20) quae a graecis schemata uel tropi dicuntur, (Bede_DeArtMet 25.31)

'which are called schemata or tropi by the Greeks'

(21) Vocatur autem corona apud Graecos etiam neutro genere $\sigma \tau \varepsilon \dot{\varepsilon} \mu \mu \alpha$, (Bede_RetInActAp 6.25)

'Among the Greeks then corona is called stemma in the neuter'

Thus collocates with verbs of calling and naming account for about 72 per cent of the tokens in this category. Once again, they typically provide a kind of etymological or gloss-like relation between the Latin text and Greek lemmata that it introduces, quotes, comments on, or uses as an illustration. The remaining 28 per cent are verbs like 'compute', 'observe', 'excel in knowledge', 'read', 'mention', 'search for knowledge', as in (22).

(22) Stadium quo graeci auctore ut dicunt hercule uiarum spatia mensurant (Bede_InLucEv vi.24.2014)

'The Greeks measured road distances in stadium, whose inventor was Hercules, as they say.'

These fit very well into the stereotype of the Greeks as scholars and sages, which is observable throughout the Anglo-Latin dataset. Only exceptionally we come across verbs like 'assemble', 'disagree', or 'seize' (Table 7). 
Table 8. 'Greeks' in collocations with verbs (Old English subcorpus)

\begin{tabular}{lrr}
\hline Greeks call/name & 47 & $61.84 \%$ \\
Greeks are X & 4 & $5.26 \%$ \\
Greeks have feuds & 4 & $5.26 \%$ \\
Greeks observe a ritual & 4 & $5.26 \%$ \\
Greeks possess/have & 2 & $2.63 \%$ \\
Greeks seize & 2 & $2.63 \%$ \\
Greeks chide/rebuke & 1 & $1.32 \%$ \\
Greeks compute & 1 & $1.32 \%$ \\
Greeks don't accept & 1 & $1.32 \%$ \\
Greeks don't eat dead animals & 1 & $1.32 \%$ \\
Greeks don't feed dead meat to swine & 1 & $1.32 \%$ \\
Greeks don't like a command & 1 & $1.32 \%$ \\
Greeks don't write on Sundays & 1 & $1.32 \%$ \\
Greeks go to communion & 1 & $1.32 \%$ \\
Greeks harass & 1 & $1.32 \%$ \\
Greeks learn & 1 & $1.32 \%$ \\
Greeks row and ride & 1 & $1.32 \%$ \\
Greeks take food & 1 & $1.32 \%$ \\
Greeks wield & 1 & $1.32 \%$ \\
\hline Total & 76 & $100.04 \%$ \\
\hline
\end{tabular}

In the Old English dataset (Table 8) 62 per cent of the collocates have verbs of calling and naming. Of these, however, 44 instances are found in medical texts, such as (23).

(23) Đeos wyrt ðe Grecas cotiledon \& Romane umbilicum ueneris nemnað byð cenned on hrofum \& on beorgum. (Lch I (Herb) (44.0))

'This herb that the Greeks call cotyledon and the Romans umbilicus veneris grows on the roofs and mountains'

The remaining 38 per cent present slightly more variety than in the Anglo-Latin subcorpus, e.g. (24) and (25).

(24) Pa Greciscan onginnað heora gear æt ðam sunstede, \& ða Egyptiscan on hærfeste. (ÆTemp (4.20))

'The Greeks begin their year at the solstice, and the Egyptians in August' 
(25) Grecas ne syllað na hyra swynum astorfen flæsc (Conf 5 (Mone) (96)) 'The Greeks never give meat of dead animals to their pigs'

Thus a scholarly text, like De temporibus anni by Ælfric, follows a familiar pattern and refers to the authority of a Greek custom in connection with a scientific problem, the calculation of the solar year and twelve months. A penitential, ${ }^{6}$ gives examples of everyday practices among the Greeks and other peoples to help confessors decide about appropriateness and heaviness of penance in similar Anglo-Saxon cases; (25) tackles carrion and whether or not it is permissible to consume or use any part of a dead animal. Among other VPs we also have instances of Greeks having feuds, observing rituals, chiding, computing, not writing on Sundays, going to communion, harassing, rowing and riding, taking food, and wielding, with most of the singular occurrences to be found again in the penitentials (examples from this genre feature prominently again in the data for the next section, see (30)). Apart from these miscellaneous examples from the penitentials, the data in this section confirm the general trend for 'Greek' collocates to occur in scholarly and scientific texts and in educational contexts.

\subsection{Other collocates and constructions}

This section is devoted to 'Greek' in non-subject NPs. These account for 13 occurrences in the Anglo-Latin dataset. Most of them are PPs (with apud or a) that describe Greek customs, especially those of language use, grammar or orthography (26).

(26) Franco. Conjugationes quot sunt? - Saxo. Apud Graecos decem. (Alc_Gramm 879.1)

'Frank. How many conjugations are there? - Saxon. Among the Greeks - ten [i.e. Greek has ten conjugations]'

A few instances also contain just nouns in an oblique case:

(27) sic que deinde Graecis admixti primo Gallograeci, postea Galatae sunt appellati. (Bede_NomReg 135)

'so then, first the Gallo-Greeks had mixed with the Greeks, and then they were called Galatians.'

6 Penitentials are "lists of sins and the penances prescribed for them. These texts governed the practice of private confession and penance in the early Middle Ages"; for an introduction to and a complete database of Anglo-Saxon penitentials see Frantzen (2013-2016). 
In the OE dataset other collocates and constructions constitute a much greater portion (Table 9), but this is largely due to examples in the Old English Orosius (24 out of 52). To take one subcategory as an example, 11 out of 22 tokens of 'Greek people' (either with overt folc or leod or with ellipsis thereof) occur in the Old English Orosius (see section 2 on Data).

Table 9. Other collocates and constructions (Old English subcorpus)

\begin{tabular}{lrr}
\hline Greek (people) in object NPs & 22 & $42.31 \%$ \\
X is/was among the Greeks & 16 & $30.77 \%$ \\
against/to/from the Greeks (= Greece) & 14 & $26.92 \%$ \\
\hline Total & 52 & $100.00 \%$ \\
\hline
\end{tabular}

Consequently many of the examples with Crecas or Creca folc deal with episodes of Greek history (28).

(28) Pa æt nihstan hie hæfden getogen eal Creca folc to ðæm gewinnum (Or 1 (14.35.1))

'At last they have drawn all the Greek people into this war.'

mid-PPs typically introduce generalised facts about the Greeks as a cultural community, which can relate to Greek poetry (29) or to religious observances (30).

(29) Omerus wæs east mid Crecum on ðæm leodscipe leoða cræftgast, Firgilies freond and lareow, pæm mæran sceope magistra betst.

(Met (30.1))

'Homer was in the east among the Greeks the most skilful in the songs of that nation, the friend and teacher of Virgil, the best of teachers for that great poet.'

(30) Mid Grecum wifmen motan onsægdnesse asecgan, ne motan swa Romane. (Conf 1.1 (Spindler) (300))

'Among the Greeks women are allowed to proclaim the sacrifice, not so among the Romans.'

About 27 per cent of the instances use a variety of PPs with 'the Greeks' to refer metonymically to the land of the Greeks, Greece; 8 such instances are found in the Old English Orosius. 
(31) Py ilcan geare he oferwon Gotan, \& hie adraf ut of Crecum.

(Or $6(25.145 .16))$

'In the same year he defeated the Goths, and drove them out of the Greeks [i.e. Greece].'

This last subcategory connects to the remaining examples of 'Greece' as a toponym.

\subsection{Greece}

Greece as a country features marginally in the Anglo-Latin dataset - 11 tokens. It is remarkable, however, that most of these instances provide information on Greek geography, provinces, and important centres. Typically, geographical or historical descriptions also include an etymological explanation:

(32) Creta: Graeciae insula centum quondam urbibus nobilis unde et $\dot{\varepsilon} \kappa \alpha \tau o ́ \mu \pi \mathrm{\prime} \lambda 1 \zeta$ dicta est. (Bede_NomReg 77)

'Crete, an island of Greece formerly (renowned) for its 100 noble cities, whence it was called hekatompolis'

(33) Graecia est prouincia Achaiae quam Graeci $E \lambda \lambda \alpha \dot{\delta} \delta \alpha$ uocant. (Bede_ExpActAp 20.3)

'Greece is a province of (Roman) Achaia, which the Greeks call Hellada'

In the OE dataset references to 'Greece' make a total of 28 occurrences. Of these, type Creca/Greca land 'the land of the Greeks' (cf. German Griechenland or Swedish Grekland) has 21 tokens and type Creca/Greca 'Greece' has 7 tokens. It should be borne in mind yet again that 17 occurrences in this subset come from the Old English Orosius (12 of Creca land and 5 of Creca). Because this text is a historical narrative, Greece features frequently as place of civil war, military conflict or destination. As with the Anglo-Latin dataset, these references often include a geographical explanation, as in (34$35)$.

(34) Morponius, Xersis pegn, forlet pa scipa pe hie on farende wæron, \& for to anre byrig on Boetium, Creca londe, \& hie abræc. (Or 2 (5.48.19)) 'Mardonius, Xerses' thane, disembarked the ships on which they had travelled and came to one of the cities in Boeotia, in Greece, and took it by storm.' 
Æfter ðæm Fuluius se consul for mid firde on Crece to pæm beorgum pe mon Olimphus hæt. (Or 4 (11.109.15))

'After this consul Fulvius came with an army to Greece, to the mountain that is called Olympus.'

For other authors Greece is mostly a point of destination or departure, occasionally included into contemporary European politics, as in the episode of Otto II's (955-983) campaigns against the Saracens from the Anglo-Saxon Chronicle (36).

(36) \& py ilcan geare for Odda Romana casere to Greclande, \& pa gemette he para Sarcena mycele fyrde cuman upp of sæ (ChronC 982.8)

'in the same year Otto, emperor of the Romans, came to Greece; and there he met a great army of the Saracens, coming up from the sea'

While in the former examples in this section (both Latin and English) Graecia and Creca(land) coincide roughly with geographical Greece of the Classical $(32,34)$, Hellenistic $(35)$, and Roman periods $(33)$, example (36) refers to the Byzantine Empire, with Otto II's expedition directed to southern Italy (cf. Swanton 1996: 124, n.8).

4. Discussion: Texts, genres, code-switching, communities of practice

This survey of the lexemes denoting 'Greek', their derivatives, collocations, and constructions has shown a strong association of the data with educational and scientific contexts. To an extent one can use search term 'Greek' to ascertain whether a particular text belongs to a particular genre: overuse of 'Greek' correlates with the genre of handbooks, scientific treatises, biblical commentary, and history (cf. similar findings on code-switching in the Helsinki Corpus by Pahta \& Nurmi 2006: 210-214). With the latter the correlation is straightforward: Greek subject matter requires frequent references to Greek provinces, cities, rulers, customs, etc. With the former three, however, it is a matter of argumentation and author/audience identification. Greek etymologies and authority are evoked, because they validate the authenticity of the claims made by the text, they make it sound important, they refer to the elevated status of Greek as a language, legitimate corresponding Latin and especially English terminology. Etymologisation in this context appears to be a particularly powerful argumentation strategy. It is also an extremely frequent one: in the Anglo-Latin subcorpus a total of 486 out of 585 tokens ( 83 per cent) and in Old English a total of 154 out of 317 (49 per cent) take part in various etymological constructions (graece, in 
graeco, graeci vocant, a graecis vocantur; on grecisc, grecas nemnað, etc.). Etymology does not only mark grammatica as a Greek word (14), but serves a heuristic function: stating that gramma is the same as littera and the same as stcef and glossing grammatica as stcefcroeft provides a clue to the understanding of the concept. It can also be used as a mnemonic device, an interpretative and argumentative tool (Copeland \& Sluiter 2009: 313, 339344). In a classroom or textbook it is a thoughtful pedagogical strategy that acknowledges the dissymmetrical mastery of the subject and linguistic code by the teacher vs. students, but at the same time makes it clear that the purpose of the communicative exchange in the textbook is to gradually reduce the dissymmetry and to introduce students to ever greater depths of knowledge (cf. Simon (2001) on code-switching in modern classroom). In biblical commentary the references to Greek are means of interpretation that get you one step closer to the 'original', and yet indirectly acknowledge the elusiveness of every original, the ungraspablility of every source text, especially the Scriptures.

One should mention that none of these textual strategies, nor the attitudes to Greek words and notions, are uniquely Anglo-Saxon (Amsler 1989; Hall 2009). Just as the text of the Old English Orosius reflects not only the Latin original of Paulus Orosius (Historiae adversus paganos) from the early fifth century but also several layers of textual accretions: additions in the manuscript of the Latin Orosius, glossaries, commentaries, even geographical maps (Bately 1980: 1xi$\mathrm{lxx}$ ), so does the language of instruction reflect the practices of generations of teachers, scholars, and philosophers, from Plato to Augustine and Isidore to Bede and Alcuin to Ælfric and Byrhtferth, who used etymology as an interpretative and argumentative tool. By adhering to genre conventions the Anglo-Saxon authors not only affirm their local and professional loyalties but also index to a wider Christian community, in which the status of Greek and the heuristic value of etymology are universally valid.

Greek lexis and etymologies, in particular, seem to proliferate during the periods of intellectual revival, when the knowledge of Greek (however superficial) becomes indicative of membership in a particular community of practice; for Aldhelm, for example, this is the community of old boys from the Canterbury school, for Ælfric that of Winchester. Yet code-switching into Greek can serve a variety of discourse-pragmatic functions. Within the heavy Latin of the hermeneutic-style tradition, Greek lexis is meant to affirm the authority of the writer and to exclude possible outsiders, the clergy of lower social standing and inferior education (Lapidge 1975; Dionisotti 1988). Flagged code-switching in handbooks and scientific treatises, on the other hand, is more inclusive. While it certainly signals a divide between the teacher and students, this type of code-switching gives a clear indication of the source language and 
provides a gloss in the matrix language of the text. Thus the students are invited to memorise Greek terms, to partake of the knowledge of the ecclesiastical community, and to aspire to one day become members of the literati among them.

\section{Conclusions}

What emerges from the data is that 'Greek' as a language was a highly influential concept. Within a similar corpus it is referred to about as frequently as the Latin language (Timofeeva 2013). The 'Greek' as a people, however, is something much more illusive, even somewhat passive: Graeci, Grecas, $p a$ Greciscan collocate frequently with verbs of saying and writing, but much less so with those of movement, and this, again, is in sharp contrast with the image of the Romans with their very agentive role in the same sources. In other words for the Anglo-Saxons the Greeks are speakers and writers of Greek, biblical Greek in particular. This would agree with the assumption shared by several historians and philologists working in Anglo-Saxon studies that the motivation for learning Greek was to be able to read the New Testament, and not to converse with the native speakers, should this exceptional chance present itself.

All in all the data are admittedly very uniform in terms of the major tendencies of how 'Greek' and 'Greeks' collocate, although, as we have seen, their distribution is much more straightforward in the Anglo-Latin dataset. If the Old English Orosius and the penitentials were removed from the general count, (something that I have done in a similar study of 'Latin' and 'Romans' usage, Timofeeva 2013: 223), the distributions in the two datasets would become even more similar; and as such would confirm our intuitive assumption that Greek was probably evoked only for the sake of the illuminative value it could add to any theological or philological discussion. Apart from the immediate purpose of using Greek as a commentary of a kind, it also serves a role of validating and authorizing the writer's utterance. This is, after all why we like to quote in Latin and Old English ourselves; it enhances our academic identity, creating a feeling of belongingness among peers and authority among students. Opening up a word or a word-hoard - explaining its etymology in whatever fanciful way was a miracle of a kind that brought order into linguistic chaos. 


\section{REFERENCES}

Adams, J. N. 2003. Bilingualism and the Latin language. Cambridge: Cambridge University Press.

Amsler, Mark. 1989. Etymology and grammatical discourse in Late Antiquity and the Early Middle Ages. Amsterdam/Philadelphia: Benjamins.

Bately, Janet. 1980. The Old English Orosius. (Early English Text Society, Supplementary series 6.) Oxford: Oxford University Press.

Bodden, Mary Catherine. 1988. Evidence for knowledge of Greek in Anglo-Saxon England. Anglo-Saxon England 17. 217-246.

Cooper-Rompato, Christine F. 2010. The gift of tongues: Women's xenoglossia in the Later Middle Ages. University Park, PA: The Pennsylvania State University Press.

Copeland, Rita \& Ineke Sluiter. 2009. Medieval grammar and rhetoric: Language arts and literary theory, $A D$ 300-1475. Oxford: Oxford University Press.

Dictionary of Old English: A to G online, ed. Angus Cameron, Ashley Crandell Amos, Antonette diPaolo Healey et al. (Toronto: Dictionary of Old English Project 2007).

Dictionary of Old English Web Corpus, compiled by Antonette diPaolo Healey with John Price Wilkin and Xin Xiang. (Toronto: Dictionary of Old English Project 2009).

Dionisotti, A. C. 1988. Greek grammars and dictionaries in Carolingian Europe. In Michael W. Herren (ed.), in collaboration with Shirley Ann Brown, The sacred nectar of the Greeks: The study of Greek in the West in the Early Middle Ages, 1-56. (King's College London Medieval Studies 2.) London: King's College Centre for Late Antique and Medieval Studies.

Durkin, Philip. 2014. Borrowed words: A history of loanwords in English. Oxford: Oxford University Press.

Feulner, Anna Helene. 2000. Die griechischen Lehnwörter im Altenglischen. (Münchener Universitäts-Schriften. Texte und Untersuchungen zur Englischen Philologie 21.) Frankfurt am Main: Peter Lang Verlag.

Frantzen, Allen J. 2003-2016. Anglo-Saxon penitentials: A cultural database. http://www.anglosaxon.net/penance/.

Hall, Thomas N. 2009. Ælfric as pedagogue. In Hugh Magennis \& Mary Swan (eds.), A companion to Elfric, 193-216. (Brill's Companions to the Christian Tradition 18.) Leiden/Boston: Brill.

Hunter Blair, Peter. 1990. The world of Bede. Reissue with corrections. Cambridge: Cambridge University Press.

Jones, Christopher A. 2009. Ælfric and the limits of 'Benedictine Reform'. In Hugh Magennis \& Mary Swan (eds.), A companion to Alfric, 67-108. (Brill's Companions to the Christian Tradition 18.) Leiden/Boston: Brill.

Lapidge, Michael. 1975. The hermeneutic style in tenth-century Anglo-Latin literature. AngloSaxon England 4. 67-111.

Lapidge, Michael. 1988. The study of Greek at the school of Canterbury in the seventh century. In Michael W. Herren (ed.), in collaboration with Shirley Ann Brown, The sacred nectar of the Greeks: The study of Greek in the West in the Early Middle Ages, 169194. (King's College London Medieval Studies 2.) London: King's College Centre for Late Antique and Medieval Studies.

Lapidge, Michael. 2006. The Anglo-Saxon library. Oxford: Oxford University Press. 
Lenker, Ursula. 2000. The monasteries of the Benedictine Reform and the 'Winchester School': Model cases of social networks in Anglo-Saxon England? European Journal of English Studies 4.3. 225-238.

Library of Latin texts, Series A. Brepolis Databases. Brepols. http://clt.brepolis.net/llta/Default.aspx.

Medieval Latin from Anglo-Saxon sources, ed. by Olga Timofeeva, Anne Gardner, Alpo Honkapohja. University of Zurich.

Miller, D. Gary. 2012. External influences on English: From its beginnings to the Renaissance. Oxford: Oxford University Press.

monumenta.ch $=$ Monumenta Informatik, ed. by Max Bänziger in cooperation with Christoph Flüeler. http://www.monumenta.ch/latein.

Pahta, Päivi \& Arja Nurmi. 2006. Code-switching in the Helsinki Corpus: A thousand years of multilingual practices. In Nikolaus Ritt, Herbert Schendl, Christiane Dalton-Puffer \& Dieter Kastovsky (eds.), Medieval English and its heritage: Structure, meaning and mechanisms of change, 203-220. (Studies in English Medieval Language and Literature 16.) Frankfurt am Main: Peter Lang Verlag.

Sawyer, John F. A. 1999. Sacred languages and sacred texts. London/New York: Routledge.

Simon, Diana-Lee. 2001. Towards a new understanding of codeswitching in the foreign language classroom. In Rodolfo Jacobson (ed.), Codeswitching worldwide II, 311-342. (Trends in Linguistics. Studies and Monographs 126.) Berlin/New York: Mouton de Gruyter.

Stephenson, Rebecca. 2009. Scapegoating the secular clergy: The hermeneutic style as a form of monastic self-definition. Anglo-Saxon England 38. 101-135.

Swanton, Michael (ed.). 1996. The Anglo-Saxon Chronicle. London: Dent.

Timofeeva, Olga. 2013. Of ledenum bocum to engliscum gereorde: Bilingual communities of practice in Anglo-Saxon England. In Joanna Kopaczyk \& Andreas H. Jucker (eds.), Communities of practice in the history of English, 201-224. (Pragmatics and Beyond New Series 235.) Amsterdam: Benjamins.

Timofeeva, Olga. 2016. Alfredian press on the Vikings: Critical discourse approach to outgroup construction. Journal of English Linguistics 44.3. 230-253.

Thorpe, Benjamin (ed.) 1844. The homilies of the Anglo-Saxon Church. The first part, containing the Sermones Catholici or Homilies of AElfric in the original Anglo-Saxon, with an English version, vol. 1. London: Ælfric Society. 